\title{
91. Verhütung experimenteller Ulcera bei der Ratte durch Phenoxybenzamin
}

\author{
G. Feifel*, B. Zboralskr und A. Hmimann-München \\ The Prevention of Experimental Ulcers \\ in the Rat with Phenoxybenzamine
}

\begin{abstract}
Summary. The formation of acute gastro-duodenal erosions cannot be explained satisfactorily by the peptic theory alone. We therefore investigated whether the action of an alpha-receptor blocking agent, such as Phenoxybenzamine, on the micro-circulation, could produce a fall in the incidence of stress ulcers in the rat stomach. Using three stress models we were able to prove that the prophylactic administration of an alpha-receptor blocking agent led to a significant decrease of the number of ulcers. These findings establish that circulatory disorders resulting from a sympathico-adrenergic reaction constitute the first phase in the formation of acute lesions of the gastric mucosa in the rat.
\end{abstract}

Zusammenfassung. Die Entstehung akuter gastroduodenaler Erosionen und Ulcera kann mit Hilfe der peptischen Theorie nicht befriedigend erklärt werden. Es wurde daher geprüft, ob durch eine Beeinflussung der Mikrozirkulation durch einen Alphareceptorenblocker (Phenoxybenzamin) eine Senkung der Ulcushäufigkeit unter Stressbedingungen am Rattenmagen zu erzielen war. Bei 3 Streßmodellen konnte nachgewiesen werden, daß die prophylaktische Gabe eines Alphareceptorenblockers zur signifikanten Senkung der Ulcushäufigkeit führt. Nach diesen Ergebnissen stellen Durchblutungsstörungen auf dem Boden einer Sympathico-Adrenergen-Reaktion den ersten Schritt bei der Bildung akuter Schleimhautschäden am Rattenmagen dar.

\section{Veränderungen an der Muskulatur der Antrumwand bei Ulcus ventriculi}

\section{LIEBERMANN-MEFFERT* und M. Allqöwer-Basel/Schweiz}

\section{Changes on the Muscle Layer of the Antrum in Gastric Ulcer Disease}

Summary. The pyloric stomach wall of 12 healthy organ donors and of resection specimens of 28 patients suffering from a gastric ulcer are investigated. The following observations were made:

1. Swelling of the pyloric-antral wall caused by hyperplasia of smooth muscle cells, edema of the submucous space, tissue augmentation.

2. Signs of degeneration of smooth muscle cells.

3. Cellular infiltration of the muscle layer by eosinophils, mastcells, lymphocytes, granulocytes and histiocytes.

4. The changes of the antral wall are independent of the location of the ulcer, suggesting a diffuse antral disease of which the ulcer appears as a sympton rather than the cause. 